\title{
Historical photographs by South African geologist Alexander L. du Toit taken along the Transandine Railway (Argentina-Chile) in 1923
}

\author{
Sharad Master ${ }^{1}$ \\ ${ }^{1}$ School of Geosciences, University of the Witwatersrand, P. Bag 3, WITS 2050, Johannesburg, South Africa. \\ Sharad.master@wits.ac.za
}

\begin{abstract}
South African geologist Alexander du Toit spent three months in 1923 doing reconnaissance mapping in South America, which resulted in his seminal 1927 work "A Geological Comparison of South America and South Africa". A few photographs taken by du Toit were published, but most were destroyed in a devasting fire in April 2021. Some surviving annotated images, giving locations, of a trip du Toit had made from Argentina to Chile on the Transandine Railway, in 1923, are reproduced here. They may help with recognizing landscape changes, such as due to melting glaciers, during the century since the photographs were taken.
\end{abstract}

Keywords: Du Toit, Landscape photographs, 1923, Chilean Andes, Río Aconcagua.

RESUMEN. Fotografías históricas del geólogo sudafricano Alexander L. du Toit tomadas a lo largo del Ferrocarril Transandino (Argentina-Chile) en 1923. El año 1923 el geólogo sudafricano Alexander du Toit pasó tres meses en América del Sur realizando un reconocimiento geológico, lo que resultó en su obra fundamental de 1927: "Una comparación geológica de América del Sur y Sudáfrica”. De este viaje se publicaron algunas fotografías tomadas por Du Toit, pero la mayoría fueron destruidas en un devastador incendio en abril de 2021. Aquí se reproducen algunas imágenes que se conservan con sus anotaciones, en las que se indican las ubicaciones, de un viaje que Du Toit realizó desde Argentina a Chile en el Ferrocarril Transandino, en 1923. Estas fotografías pueden ayudar a reconocer los cambios del paisaje, como los debidos al derretimiento de los glaciares, durante el siglo transcurrido desde que ellas fueron tomadas.

Palabras clave: Du Toit, Fotografias de paisajes, 1923, Andes chilenos, Río Aconcagua.

\section{Introduction}

South African geologist Alexander Logie du Toit (1878-1948) was one of the foremost proponents of the idea of Continental Drift, as proposed by Alfred Wegener (e.g., Wegener, 1924). Du Toit started his career with the Geological Commission of the Cape of Good Hope in 1903, which subsequently became part of the Geological Survey of South Africa. For 17 years, he mapped a large part of the Cape and Karoo Basins, encompassing their entire stratigraphic ranges (Gevers, 1950; Master, 2020, 2021a; Chetty, 2021). He was also an expert on Karoo paleobotany (Master, 2021b). Quite early on, he had established himself as one of the pre-eminent authorities on Cape geology, and he contributed to the second edition of the Geology of Cape Colony (Rogers and du Toit, 1909). He incorporated the results of his mapping in his Geology of South Africa (Du Toit, 1926a). In 1923, Du Toit obtained a grant from the Carnegie Institution in Washington, D.C. to spend three months in South America, 
doing reconnaissance mapping in Brazil, Uruguay and Argentina, in order to compare the rocks there with those he had mapped in the Cape Province of South Africa. Some 8 years earlier, Keidel (1916) had already made a comparison of the rocks of the Sierras in Buenos Aires Province of Argentina, with those of the Cape mountains of South Africa.

$\mathrm{Du}$ Toit came to South America by ship, and worked his way from southern Brazil, into Uruguay, and then to Argentina, where he mapped in the Sierras de Tandil, the Sierra de la Ventana, and mainly in the region of the Argentinian Precordillera, around Córdoba, San Juan, Barreal and Mendoza. The results of his rapid reconnaissance mapping of this vast area, done within the remarkably short time of three months, were presented initially by Du Toit (1926b), and then was published as a substantial monograph (Du Toit, 1927). Du Toit's work was well received in South America, but because so few copies of his 1927 monograph had been printed by the Carnegie Institution, there was a huge demand for this work, and he was persuaded to produce a second edition, in Portuguese translation, which was eventually published in Brazil four years after his death (Du Toit, 1952). Du Toit, in his correspondence with South American colleagues, had often expressed a wish to return to South America, but he never did. Some of du Toit's work in South America, and his dealings with Argentinian geologists, has been discussed by Cingolani (2008).

Du Toit arrived in Brazil in August 1923. He spent a short time in Uruguay, then went to Argentina in September 1923. On this trip, du Toit was accompanied by his wife, Evelyn. At the end of the mapping exercise, du Toit and his wife made a journey by train from Uspallata in the Argentinian Pre-Cordillera, along the Transandine Railway to Los Andes, Chile, eventually making it by road to the Chilean port city of Valparaíso, and the adjacent coastal resort of Viña del Mar, on 2 October 1923. The 1 meter-gauge Transandine Railway ("Ferrocarril Transandino"), extending from Mendoza, Argentina, to Los Andes, Chile, was built by the Clark Brothers, and opened in 1910 (Barclay, 1910). It follows an ancient historic route through the Andes, connecting Argentina and Chile, and is the subject of numerous classical researches in the history of geology, including by Charles Darwin (Ramos, 1994, 2009; Cegarra and Ramos, 2008).
During the train journey, Du Toit took a number of photographs with a large format camera, whose negatives were postcard-sized. As was his lifelong habit, he later annotated the photographic negatives in ink along their margins, giving details of the photographed scene, including in many cases, the date, the look direction, and the name of the geological entity or formation. The journey began in Uspallata, and the first photograph shows the scenery between Uspallata and the Chilean border, consisting of hills draped with screes and gravels. The rest of the photographs show scenes along the Río de Aconcagua (Río Aconcagua), the region near Juncal and Los Cuevas, and the stretch from Frontera to Los Andes. Two photographs, taken in Valparaíso and Viña del Mar, are part of this series, and are included for their historical interest. At Viña del Mar, Du Toit got his first view of the eastern Pacific Ocean (he had seen the western Pacific from the east coast of Australia in 1914). He was to see the Pacific again in California in 1933, and he wrote an article about its evolution for the Pacific Science Congress in 1940 (Du Toit, 1940). The geology of the region encompassed by Du Toit in his journey from the Argentinian Precordillera to the Pacific coast has been described, among many others, by Ramos (1988, 1994), Mpodozis and Ramos (1990), Cegarra and Ramos (2008), and their contained references.

Du Toit (1927) published a number of photographs related to his field work in Brazil, Uruguay and Argentina. Because the Andes were not part of the Gondwana supercontinent, du Toit did not study them, and his published work on South America does not include any of his observations on Chilean geology. His South American photographs, together with their annotated negatives, were part of the Alex du Toit Papers BC722 at the Jagger Library, University of Cape Town. On 18 April 2021, a wildfire on the slopes of Table Mountain above the University of Cape Town spread to part of its campus, and the Jagger Library was almost completely destroyed in a devastating fire. Fortunately, part of its holdings, including the Alex du Toit Papers, was housed in the basement, and escaped the conflagration, with some water damage. However, the entire photographic collection of the Alex du Toit archive, including all negatives and original photographs, was destroyed in the conflagration. Some of the photographs, especially those relating to Southern Africa, had been scanned electronically, as part of a Landscape Change 
project of Prof. Timm Hofmann at the University of Cape Town (Scott et al., 2017). The precious photographs from South America, and other parts of the world, such as the USA and USSR, that du Toit had taken at various times, were unfortunately lost. The author has been working on the Alex du Toit archives for a number of years, and he was allowed to take many photographs. Among those, he managed to take images of the prints of du Toit's Chilean photographs, superimposed on the annotated borders of the negatives of the same photographs. This was done in order to link the photographs with their descriptions. The original negatives were meant to be scanned later for high-quality reproductions of the original photographs. Because of their destruction in the fire, the images taken by the author are all that remain of du Toit's original photographs. They are reproduced here with minimal cropping, showing du Toit's annotations, which are also transcribed in the captions, and given in inverted commas. Du Toit called the Transandine Railway the "Transandean Railway", and his terminology is retained in the quotes. Du Toit must have misheard (or misremembered) the name of Juncal, on the Argentina-Chile border, and referred to it as "Cuncal" in his later annotations on the negatives. The name has been corrected as "Juncal" in the captions. Just as Du Toit's early photographs are being used for quantifying the effects of landscape change over almost a century, in Southern Africa (Scott et al., 2017), so too could his Andean photographs be useful for similar purposes. Some of his images show the moraines, and also distant glaciated mountains in the Aconcagua region, and could be used for evaluating the effects of melting of the glaciers due to climate change. His image of Viña del Mar was taken before the current Presidential Palace was built there in 1928. Even without any utilitarian motives, du Toit's photographs are important historical documents, being dated, and well-located, and being part of a famous excursion by one of the best-known geologists of the first half of the Twentieth Century.

\section{Photographs}

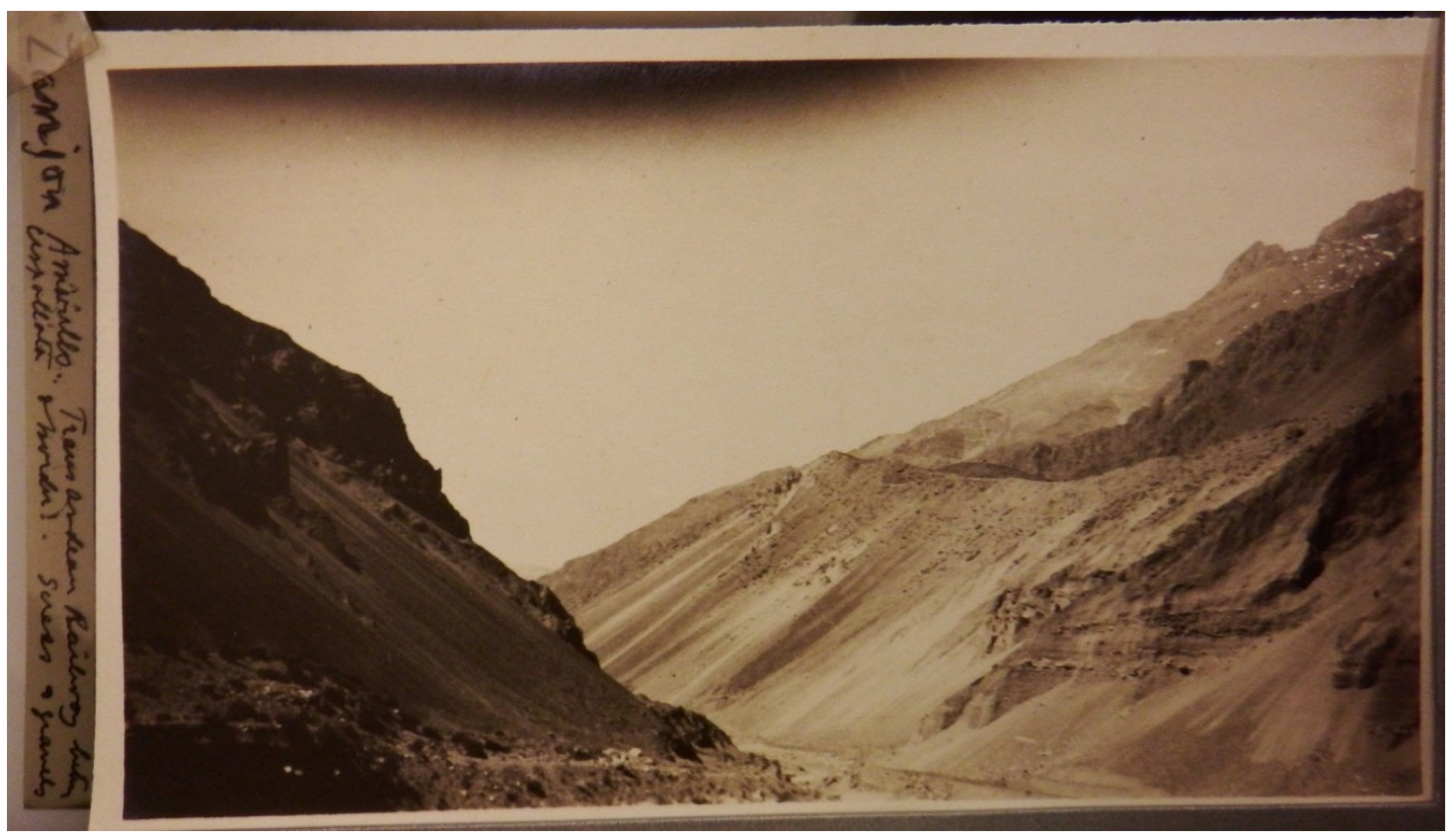

PHOTO 1. "Lanjon Amarillo, Transandean Railway between Uspallata and border. Screes and gravels." 


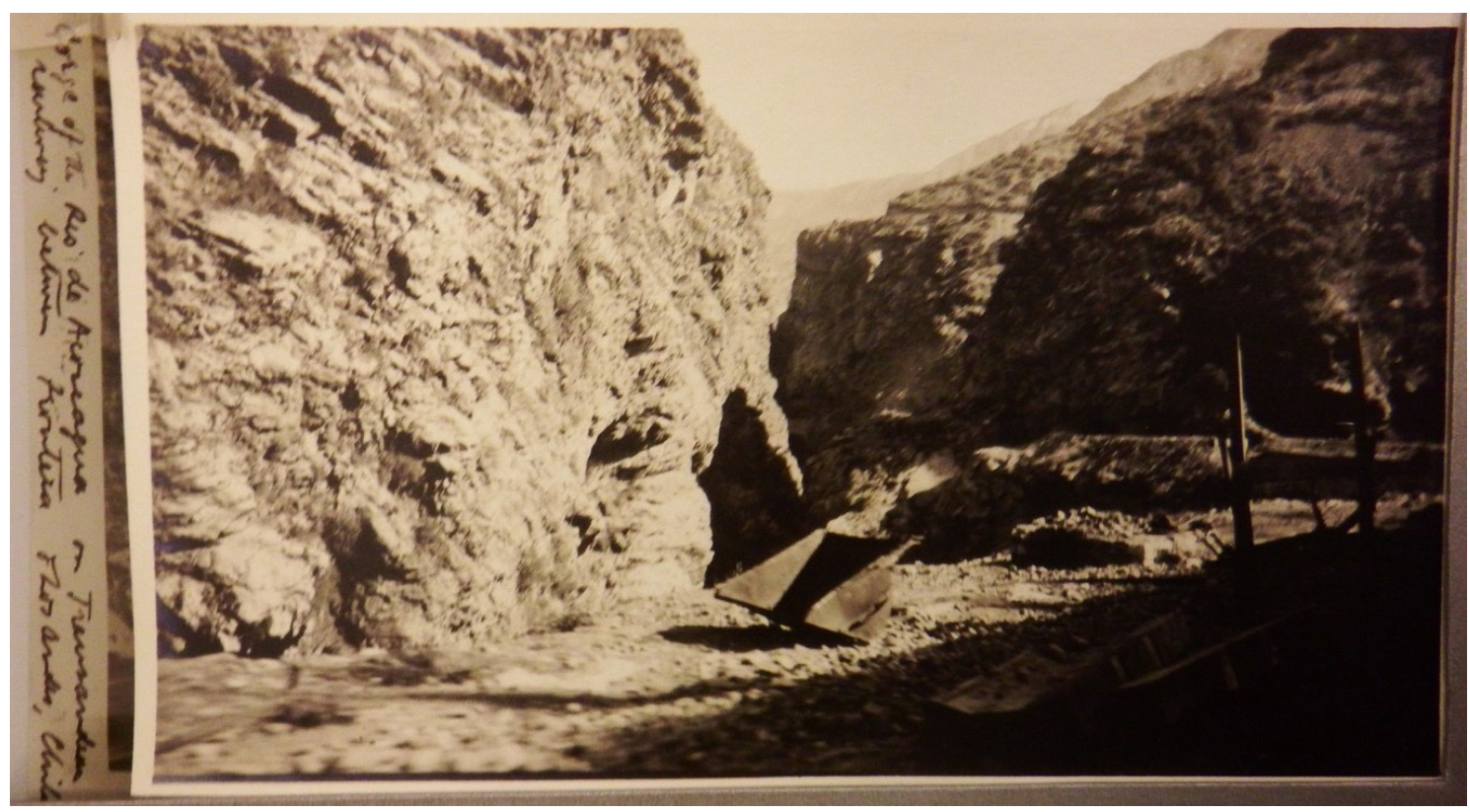

PHOTO 2. "Gorge of the Río de Aconcagua on Transandean Railway between Frontera and Los Andes, Chile."

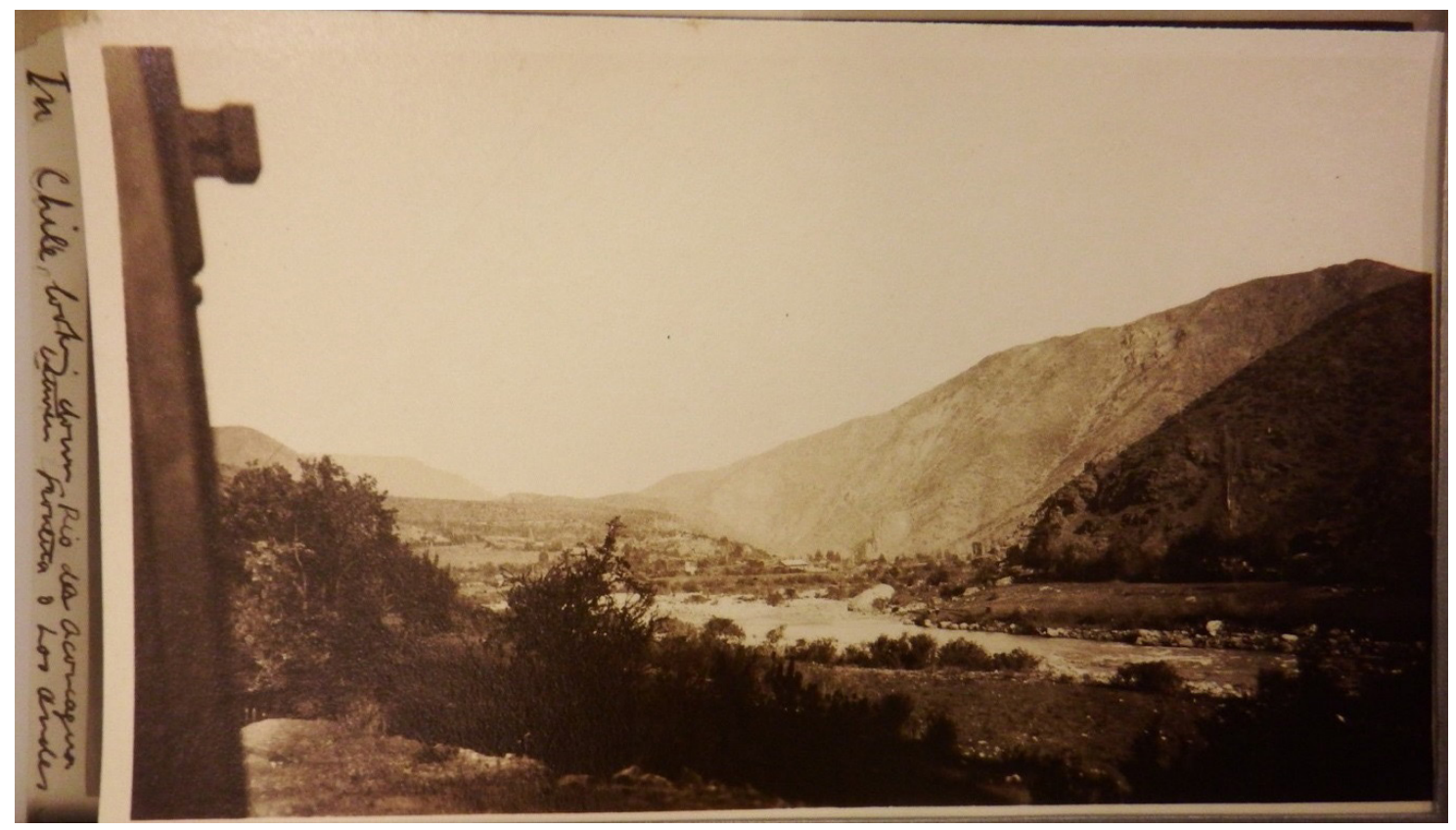

PHOTO 3. "In Chile looking down the Río de Aconcagua between Frontera and Los Andes." 


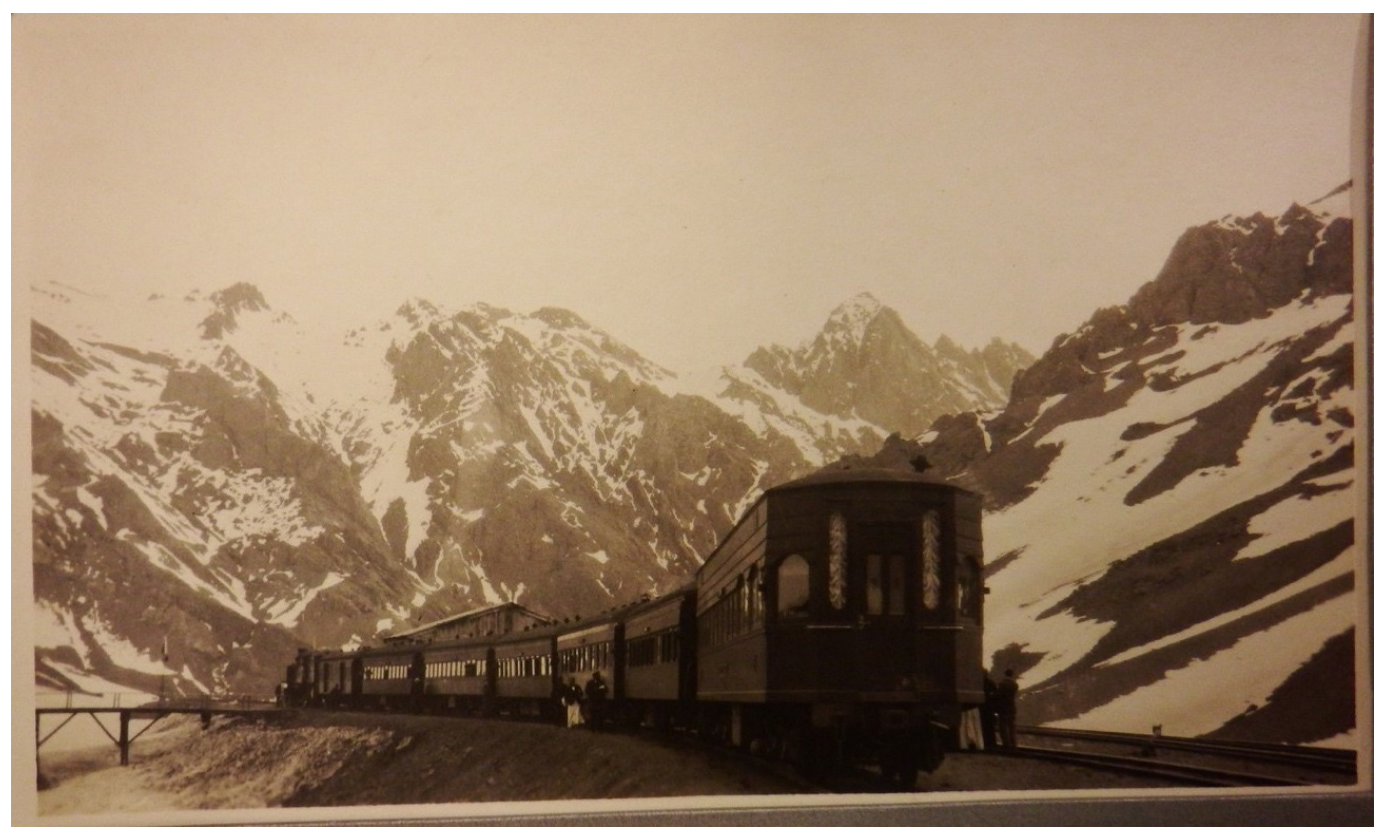

PHOTO 4. Train on the Transandine Railway in the Andes.

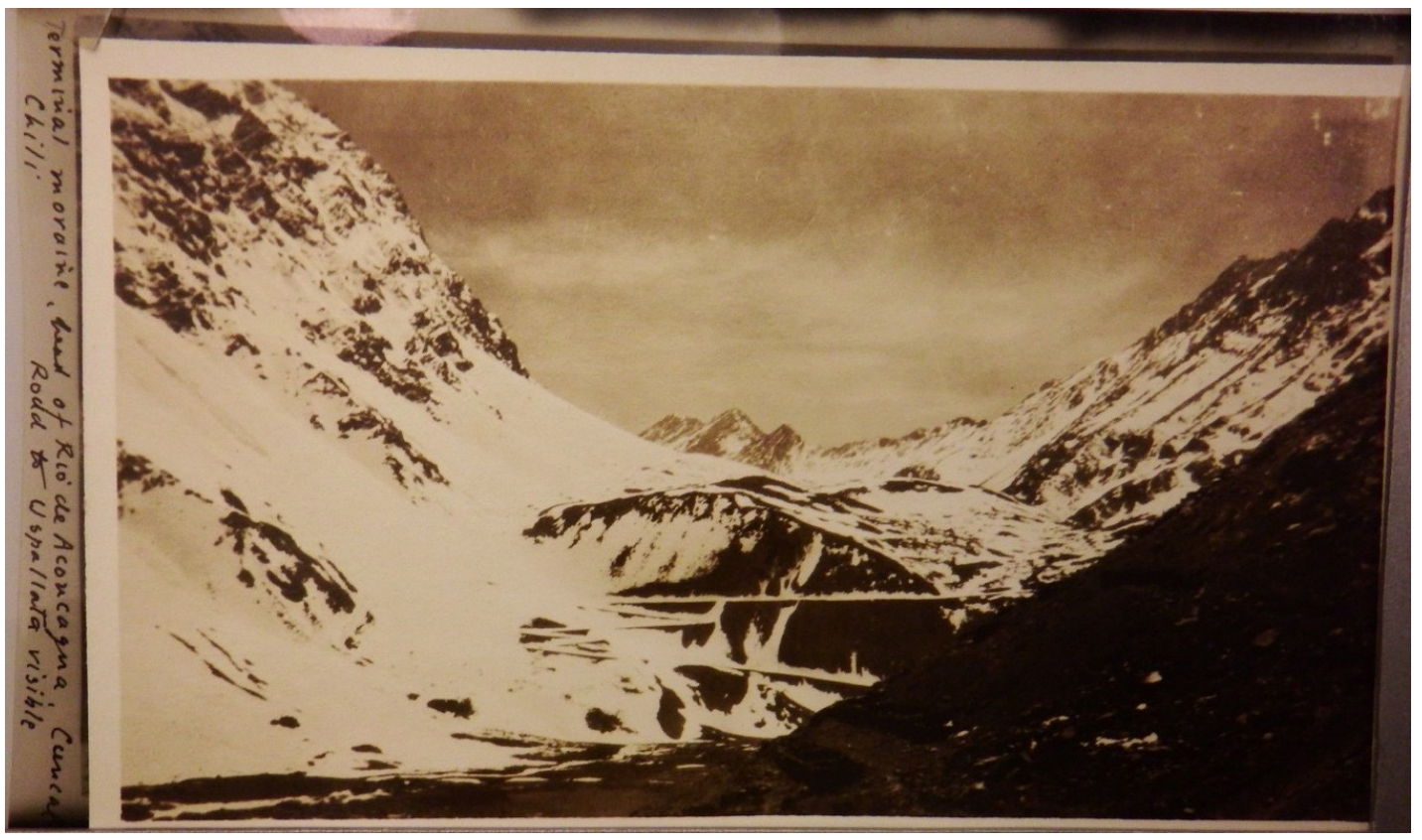

PHOTO 5. "Terminal moraine, head of Río de Aconcagua. Juncal Road to Uspallata visible." 


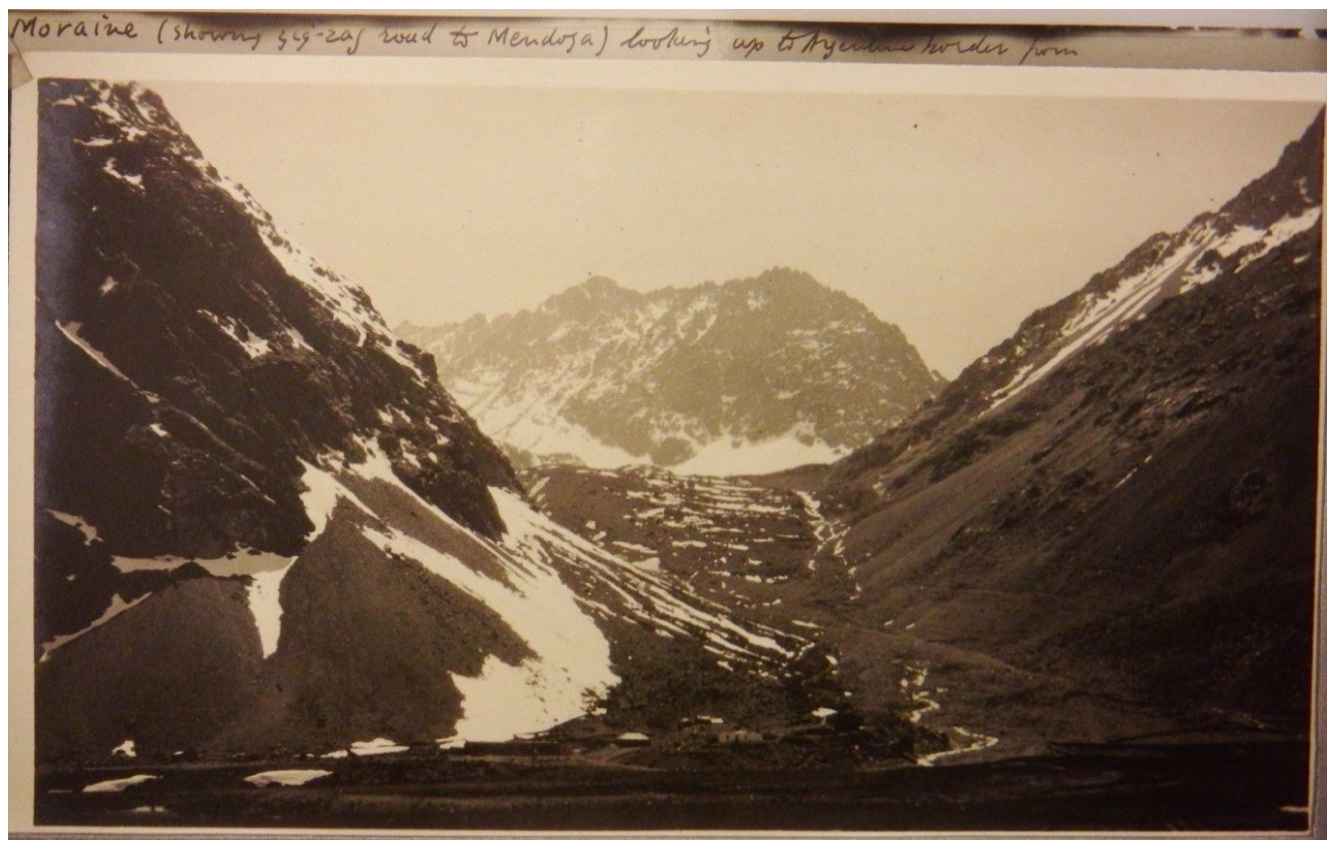

PHOTO 6. "Moraine (showing zig-zag road to Mendoza) looking up to Argentinian border."

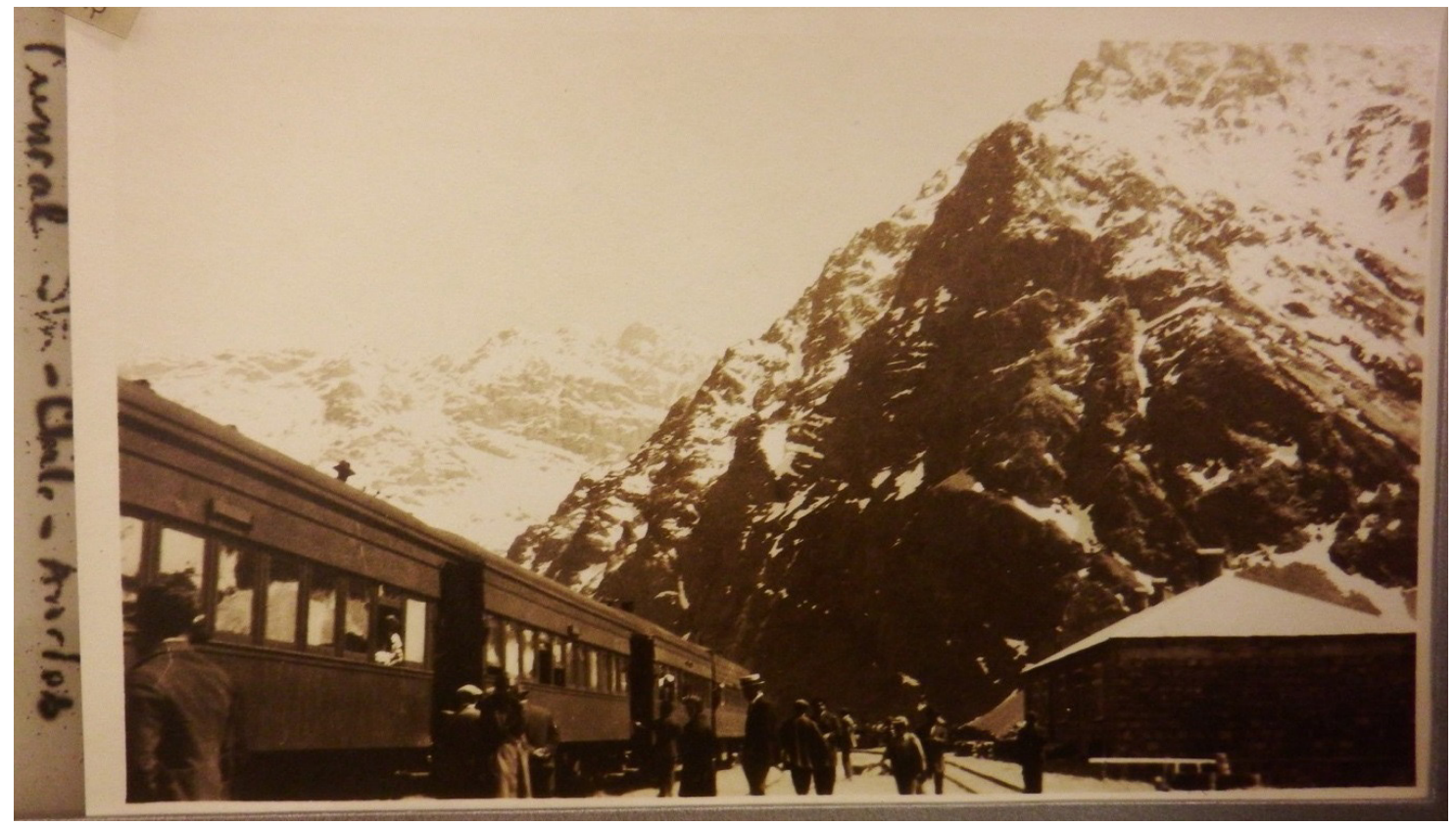

PHOTO 7. "Juncal Station, Chile." 


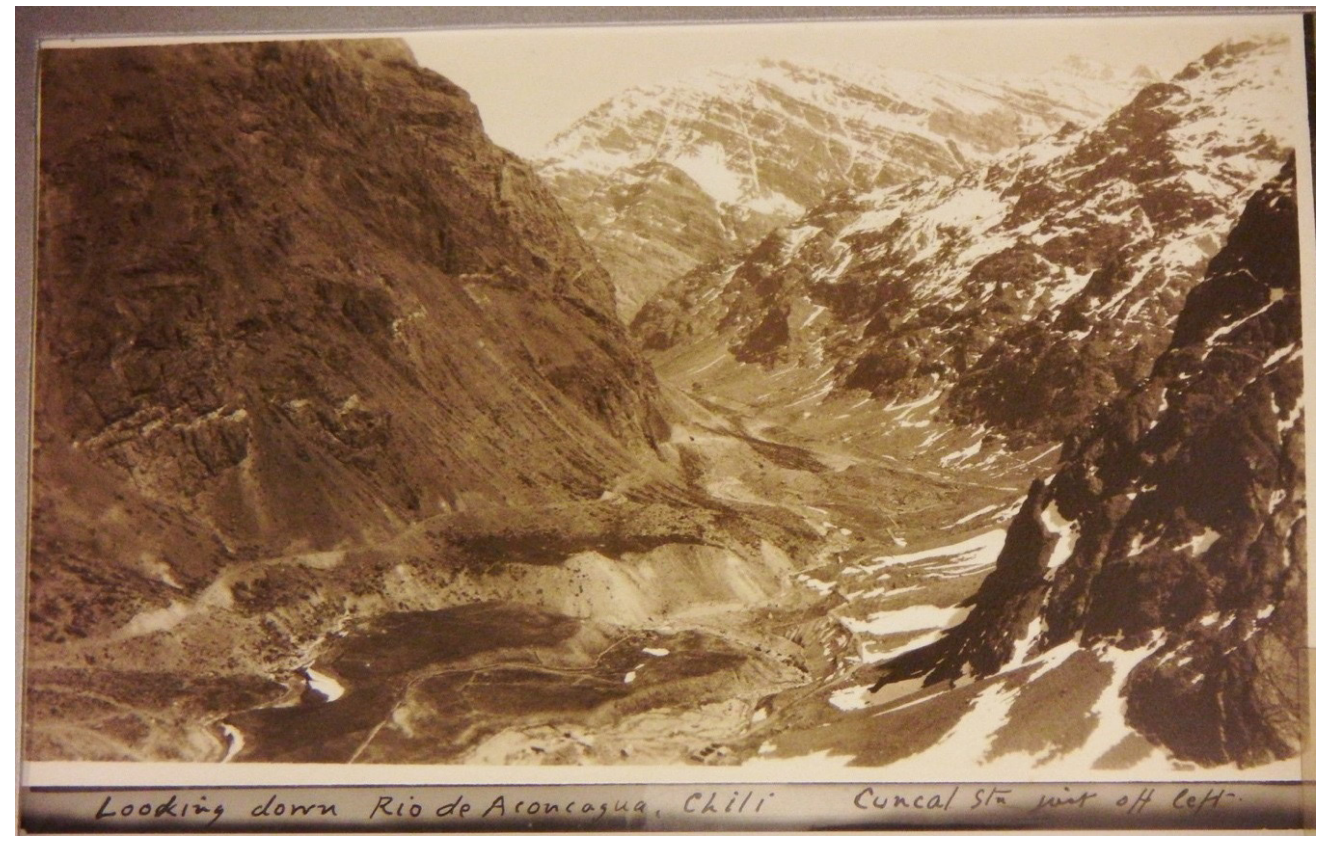

PHOTO 8. "Looking down Río de Aconcagua, Chili. Juncal Stn. just off left.”

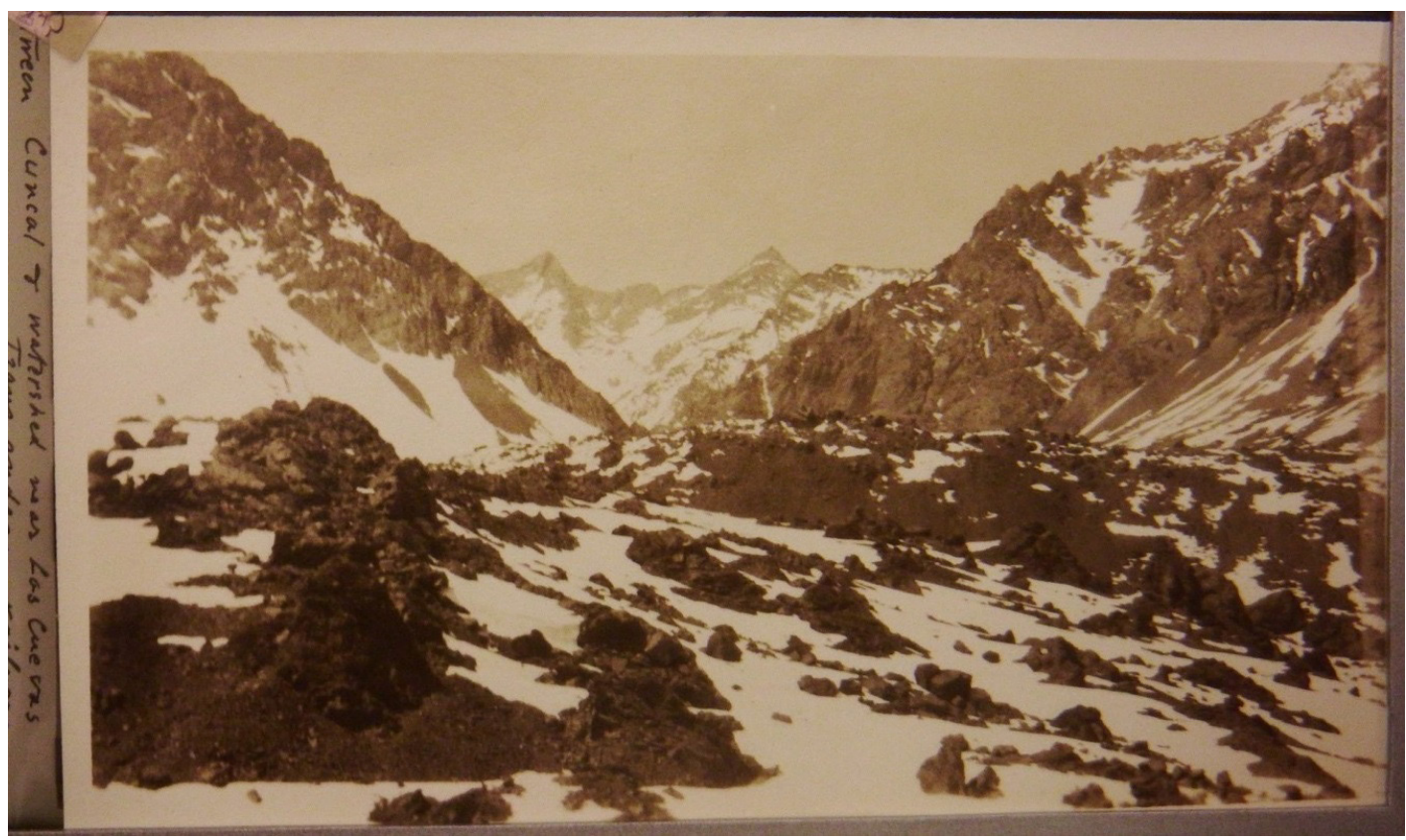

PHOTO 9. "Between Juncal and watershed near Las Cuevas, Transandean Railway." 


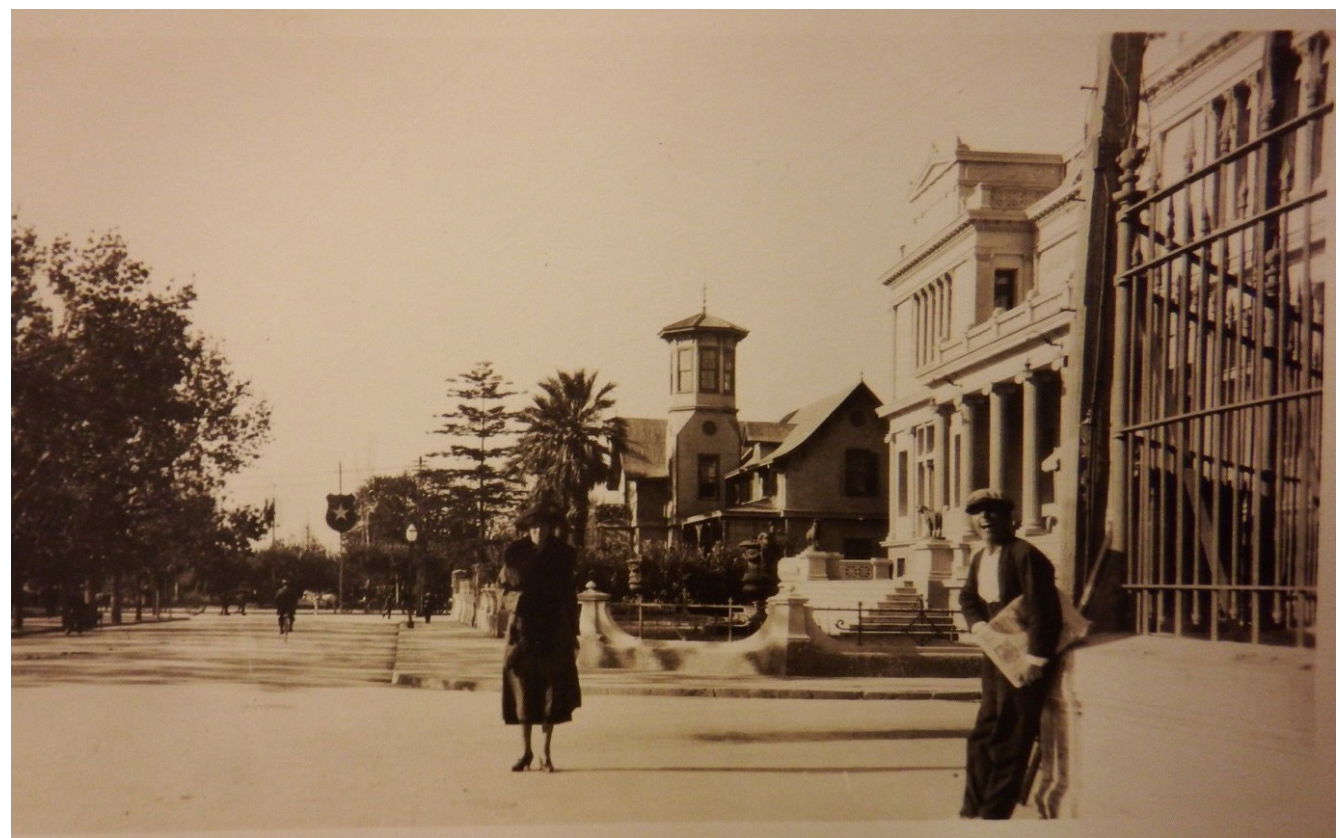

PHOTO 10. Mrs Evelyn du Toit, in Valparaíso, Chile, 2 October 1923. Note vendor carrying newspapers with large photographs on the front page.

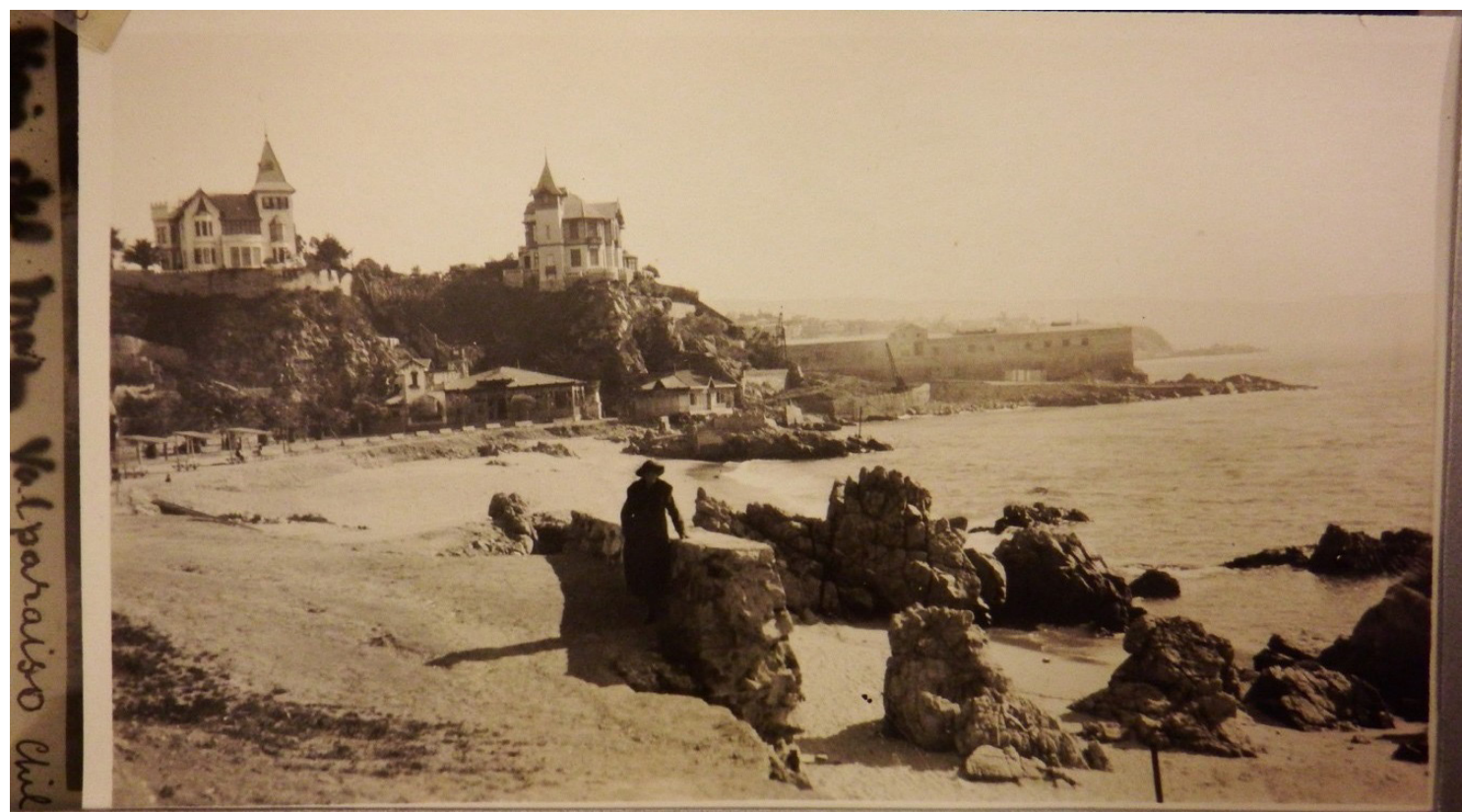

PHOTO 11. Mrs. Evelyn du Toit posing at a ruined wall, near rocky outcrops at Viña del Mar, Chile, 2 October 1923. In the background is Cerro Castillo, with buildings that appear to be the precursors of the present day Presidential Palace (Palacio Presidencial), and Wulff Castle (Castillo Wulff). 


\section{Acknowledgments}

I am grateful to the Jagger Library (and particularly to Clive Kirkwood of Special Collections) at the University of Cape Town, for permission to take the photographs, and to reproduce them here. Funding from the School of Geosciences, University of the Witwatersrand, and from CIMERA, is gratefully acknowledged. I thank W. Vivallo for editorial corrections, and F. Hervé for reviewing the manuscript.

\section{References}

Barclay, W.S. 1910. The First Transandine Railway. Geographical Journal 36 (5): 553-562.

Cegarra, M.I.; Ramos, V.A. 2008. Cerro Aconcagua: La cumbre más alta de América. CSIGA (Editor), Sitios de Interés Geológico de la República Argentina. Instituto de Geología y Recursos Minerales, Servicio Geológico Minero Argentino, Anales 46 (1): 446 p. Buenos Aires.

Chetty, S. 2021. 'Africa forms the Key'. Alex du Toit and the History of Continental Drift. Palgrave McMillan: 271 p. Cham.

Cingolani, C.A. 2008. Alex. L. du Toit (1878-1948): Semblanzas de su vida y de su aporte al conocimiento de la Geología Sudamericana. Historia de la Geología Argentina I, Serie Correlación Geológica 24: 251-266.

Du Toit, A.L. 1926a. The Geology of South Africa. Oliver and Boyd: 463 p. Edinburgh.

Du Toit, A.L. 1926b. Comparative study of late Palaeozoic and early Mesozoic formations of South America, South Africa, Australia and India. Yearbook of the Carnegie Institution of Washington 25 (1925-1926): 402-403.

Du Toit, A.L. 1927. A geological comparison of South America and South Africa. Publications of the Carnegie Institution of Washington 381: 1-158.

Du Toit, A.L. 1940. Observations on the evolution of the Pacific Ocean. In Pacific Science Congress of the Pacific Science Associaion, No. 6. Proceedings 5 (1):175-182. Los Angeles.

Du Toit, A.L. 1952. Comparação Geológica Entre a América do Sul e a África do Sul. Serviço Gráfico do Instituto Brasileiro de Geografia e Estatística: 179 p. Rio de Janeiro.

Gevers, T.W. 1950. The life and work of A.L. du Toit. A.L. du Toit Memorial Lecture No. 1. Geological Society of South Africa: 109 p. Johannesburg.
Keidel, J. 1916. La Geología de las Sierras de la Provincia de Buenos Aires y sus relaciones con las montañas de Sud África y los Andes. Anales del Ministerio de Agricultura de la Nación, Sección Geología, Mineralogía y Minería 11 (3): 1-78. Buenos Aires.

Master, S. 2020. A few hours in the Seychelles with Alex du Toit in 1938. South African Journal of Science 116 (7-8). doi: 10.17159/sajs.2020/7747.

Master, S. 2021a. Politics of fossils and the Royal Society: Two letters from Robert Broom to Alex du Toit (19411942). Transactions of the Royal Society of South Africa 76 (1): 97-101. doi: 10.1080/0035919X.2020.1856214.

Master, S. 2021b. The correspondence between South African geologist Alex L. du Toit and Indian palaeobotanist Birbal Sahni concerning Gondwana palaeobotany (1925-1944). The Palaeobotanist, Lucknow 69 (1-2): 119-137.

Mpodozis, C.; Ramos, V.A. 1990. The Andes of Chile and Argentina. In Geology of the Andes and its relation to Hydrocarbon and Mineral Resources (Ericksen, G.E.; Cañas Pinochet, M.T.; Reinemud, J.A.; editors). Circumpacific Council for Energy and Mineral Resources, Earth Sciences Series 11: 59-90. Houston.

Ramos, V.A. 1988. The Tectonics of the Central Andes: $30^{\circ}$ $33^{\circ} \mathrm{S}$ latitude. In Processes in Continental Lithospheric Deformation (Clark, S.; Burchfiel, D.; Suppe, J.; editors). Geological Society America, Special Paper 218: 31-54. Boulder.

Ramos, V. 1994. Field Guide: Geology of the Cordillera Principal. Secretería de Minería de la Nación, Direccion Nacional del Servico Geológico, and Asociación Geológica Argentina, Publicación 157: 30 p. Buenos Aires.

Ramos, V.A. 2009. Darwin at Puente del Inca: observations on the formation of the Inca's Bridge and mountain building. Revista de la Asociación Geológica Argentina 64 (1): 170-179.

Rogers, A.W.; Du Toit, A.L. 1909. An Introduction to the Geology of Cape Colony, $2^{\text {nd }}$ edition. Longmans, Green and Co: 491 p. London.

Scott, S.L.; Rohde, R.F.; Hoffman, M.T. 2017. Repeat landscape photography, historical ecology and the wonder of digital archives in southern Africa. African Research and Documentation 131: 35-47.

Wegener, A. 1924. The Origin of Continents and Oceans. Translated from the $3^{\text {rd }}$ German edition by J.G.A. Skerl; with an introduction by John W. Evans. Methuen: 212 p. London. 